\title{
Detection of free radical scavenging activity of dhaura, anogeissus acuminata (roxb) wall ex bedd in vitro
}

\begin{abstract}
The free radical inhibitory activity of Dhaura, Anogeissus acuminata extracted in chloroform, ethanol and water was investigated in vitro. The DPPH inhibition by the different stem extract depended on the concentration and the ethanol extract was found to be the most potent as the lower concentration of it was most effective in scavenging different free radicals. The analysis of superoxide radical scavenging activity showed that the aqueous extract was most effective when compared to chloroform and ethanol extracts. The different extracts of Dhaura also inhibited the generation of nitric oxide radical depending on its concentration and maximum effect was observed at $200 \mu \mathrm{g} / \mathrm{ml}$. Our study indicates that free radical scavenging activity of Dhaura affirms the medicinal use by the practitioners of folklore medicine.
\end{abstract}

Keywords: anogeissus acuminata, DPPH, superoxide, nitric oxide, endoplasmic reticulum, peroxisomes, mitochondria
Volume 12 Issue 4 - 2019

\section{Ganesh Chandra Jagetia, Zairempuii \\ Department of Zoology, Mizoram University, India}

Correspondence: Ganesh Chandra Jagetia, Department of Zoology, Mizoram University, India, Email gc.jagetia@gmail.com

Received: August 5, 2019 | Published: August 27, 2019
Abbreviations: EDTA, ethylenediaminetetraacetic acid; NBT, nitrobluetetrazolium; TCA, trichloroacetic acid; NED, N-(1Naphthyl)ethylenediamine dihydrochloride

\section{Introduction}

The free radical generation is a universal phenomenon in eukaryotes utilizing oxygen for their energy requirements. The endoplasmic reticulum, peroxisomes, mitochondria, and lysosomes are the major sites of free radical generation in a cell. ${ }^{1-3}$ The free radicals are also generated by redox cycling of xenobiotics, exposure to ionizing radiations, radiofrequency and microwave radiations, visible light and UV radiation, many chemicals, oxygen- the most essential element of life, endogenous compounds and photosensitizing drugs. ${ }^{4-8}$ These free radicals trigger oxidative stress, which is one of the most important events in disease process and pathophysiology. It is not surprising that all most all diseases can be linked to triggering of oxidative stress and hence free radical formation in humans. ${ }^{9-11}$ Several synthetic drugs have been used to reduce oxidative stress however, they induce adverse toxic side effects. ${ }^{12,13}$ The use of plant derived or herbal products may be useful as antioxidants as they may not exert toxic adverse effects due to their biologic origin and composite nature.

Dhaura (Hindi) or Anogeissus acuminate- family Combretaceae grows up to a height of 40meters in semi-deciduous forests in India, Cambodia, Bangladesh, Laos, Myanmar, Arabian Peninsula, Thailand, Vietnam, and Africa. ${ }^{14,15}$ It is found in tropical and semideciduous regions of India. It has been used as a medicine in the Indian system of medicine, the Ayurveda. The Ayurveda describes it as an acrid, alexipharmic, bitter, astringent, cooling, and vulnerary. The roots of Dhaura are used for the treatment of asthma, dysentery, fatigue, leprosy, burning sensations, vaginal and uterine complaints, inflammations, leukoderma and blood diseases. The decoction prepared by boiling its roots in water reduces toothache after gargling. ${ }^{15}$ The amoebic dysentery, diarrhea, bleeding piles and urinary infections can also be treated by using Dhaura. ${ }^{15,16}$ Dhaura is utilized to treat skin disorders, neurological problems, general weakness, bronchitis, impotence, enlargement of spleen cold, dysuria, cough, excessive perspiration, cholera, urinary disorders, snake bite and in scorpion sting. ${ }^{15}$ The gum produced by Dhaura is called Ghatti or Indian gum and is used as a tonic after delivery. ${ }^{15,16}$ The preclinical studies have shown the alleviation of alloxan-induced diabetes in rats. ${ }^{17}$. The hydroalcoholic extracts of leaves and stem bark of Dhaura has been reported to be antioxidant and hepatoprotective in Wistar rats. ${ }^{18}$ The present study was undertaken to estimate the antioxidant activity of different stem bark extracts of Dhaura i.e. Anogeissus acuminata in vitro.

\section{Materials and methods}

\section{Chemicals}

Analytical grade chemicals and MilliQ (18 $\Omega$ ) water were used for entire analyses. Dimethylsulfoxide (DMSO), 1,1Diphenyl-2-picrythydrazyl (DPPH), nitrobluetetrazolium (NBT), ethylenediaminetetraacetic acid (EDTA), trichloroacetic acid (TCA), sodium nitroprusside, sulfanilamide, $\mathrm{N}$-(1-Naphthyl)ethylenediamine dihydrochloride (NED), and orthophosphoric acid were procured from Sigma Aldrich Chemicals co, Kolkata, India. Methanol, petroleum ether, chloroform, ethanol, sodium carbonate, sodium hydroxide, sodium chloride, potassium chloride, potassium nitrite, disodium hydrogen phosphate (anhydrous), potassium dihydrogen phosphate, aluminum chloride, ferrous ammonium sulphate, ammonium acetate, glacial acetic acid and acetyl acetone were procured from Merck India Ltd., Mumbai.

\section{Preparation of extracts}

Dhaura or Anogeissus acuminata belongs to family: Combretaceae. It is also known as button tree, Anogeissus pendula Edgew. Conocarpus acuminatus Roxb. ex DC. It was identified by the Department of Horticulture Aromatic and Medicinal Plants, Mizoram University, Aizawl, India. The mature non-infected stem bark of Dhaura was removed from the plant from the Mizoram University campus during the months of September to December and cleaned 
by washing thoroughly in water so as to remove the dust and other unnecessary extraneous material. The washed stem bark and shade dried cut into small pieces and ground into powder in an electrical grinder. The dried powder of Dhaura was sequentially extracted in petroleum ether, chloroform, ethanol and water using Soxhlet apparatus.

\section{Free radical scavenging estimation}

DPPH free radical scavenging activity: The DPPH inhibitory activity of chloroform, ethanol and water extracts were estimated as described earlier. ${ }^{19}$ with minor modifications. One $\mathrm{ml}$ of $0.1 \mathrm{mM} \mathrm{DPPH}$ in methanol was added to the different concentrations of various extracts of Dhaura $(0.5 \mathrm{ml}$ each). After mixing thoroughly, the mixture was allowed to stand in the dark for $30 \mathrm{~min}$ and the absorbance was measured at $517 \mathrm{~nm}$ using a UV-VIS spectrophotometer (SW 3.5.1.0. Biospectrometer, Eppendorf India Ltd., Chennai). The methanol was used for the baseline correction. The results have been compared with that of the control prepared as described above but without sample. DPPH radical scavenging activity has been expressed as a percentage and was calculated using the following formula:

$$
\% \text { Scavenging }=\left(A_{\text {control }}-A_{\text {sample }}\right) / A_{\text {control }} \times 100
$$

Where $A_{\text {sample }}$ is the absorbance of the test sample and $A_{\text {control }}$ is the absorbance of the control.

Superoxide anion scavenging activity: Superoxide scavenging activity was detected by the method of Hyland et al. ${ }^{20}$ The reaction mixture contained $0.2 \mathrm{ml}$ of NBT $(1 \mathrm{mg} / \mathrm{ml}$ in DMSO), and $0.06 \mathrm{ml}$ different doses of different extracts and standard in $2 \mathrm{ml}$ of alkaline
DMSO (1ml DMSO containing $5 \mathrm{mMNaOH}$ in $0.1 \mathrm{ml} \mathrm{H}_{2} \mathrm{O}$ ) Superoxide free radicals formed by alkaline DMSO react with NBT to produce coloured diformazan. The blank consisted of pure DMSO instead of alkaline DMSO. The absorbance was read at $560 \mathrm{~nm}$ using UV-VIS spectrophotometer. The percentage inhibition of superoxide anion generation was calculated using the following formula.

$$
\% \text { Inhibition }=\left(A_{o}-A_{1}\right) / A_{o} x 100
$$

Where $A_{o}$ is the absorbance of the control and $A_{1}$ is the absorbance of different extracts of Anogeissus acuminata and standard.

Nitric oxide scavenging activity: Nitric oxide scavenging activity was determined by the earlier method. ${ }^{21}$. Nitric oxide generated by sodium nitroprusside is converted into nitrous acid in contact with air and it can be easily measured using Greiss reagent. Sodium nitroprusside $(5 \mathrm{mM})$ in PBS was mixed with different concentrations of various extracts and incubated at $25^{\circ} \mathrm{C}$ for $150 \mathrm{~min}$. The samples from the above were reacted with Greiss Reagent $\left(1 \%\right.$ sulfanilamide, $2 \% \mathrm{H}_{3} \mathrm{PO}_{4}$, and $0.1 \%$ NDD). The absorbance of the chromophore formed during diazotization of nitrite with sulfanilamide and subsequent coupling with NED was read at $546 \mathrm{~nm}$ using a UV Spectrophotometer and referred to the absorbance of standard solutions of potassium nitrite treated in the same way with Greiss reagent. The blank consisted of PBS and equal ratio of sodium nitroprusside and Greiss reagent treated in an identical manner without the test sample.

\section{Results}

The results of this study are presented in tables 1-3 and Figures 1-9 as mean \pm SEM, (standard error of the mean.

Table I DPPH radical scavenging activity of chloroform, ethanol and aqueous extracts of Anogeissus acuminata

\begin{tabular}{llll}
\hline \multirow{2}{*}{$\begin{array}{l}\text { Concentration } \\
(\mu \mathrm{g} / \mathrm{ml})\end{array}$} & \multicolumn{3}{l}{ Percent inhibition $(\mathrm{mean} \pm \mathrm{SEM})$} \\
\cline { 2 - 4 } & \multicolumn{3}{l}{ Anogeissus acuminata Extract type } \\
\cline { 2 - 4 } & Choloroform & Ethanol & Aqueous \\
\hline 20 & $33.73 \pm 1.32$ & $57.34 \pm 0.26$ & $72.76 \pm 0.09$ \\
40 & $44.11 \pm 0.17$ & $88.12 \pm 0.65$ & $76.66 \pm 0.11$ \\
60 & $53.37 \pm 0.66$ & $92.65 \pm 0.13$ & $84 \pm 0.16$ \\
80 & $69.18 \pm 0.92$ & $92.71 \pm 0.45$ & $87.04 \pm 0.25$ \\
100 & $74.01 \pm 0.62$ & $88.77 \pm 0.41$ & $88.38 \pm 0.094$ \\
120 & $77.24 \pm 0.66$ & $8721 \pm 0.11$ & $88.85 \pm 0.16$ \\
140 & $67.77 \pm 0.36$ & ---- & $80.66 \pm 0.013$ \\
160 & $63.14 \pm 0.17$ & ---- & $79.91 \pm 0.19$ \\
180 & ---- & --- & $78.95 \pm 0.09$ \\
200 & --- & --- & $76.76 \pm 0.25$ \\
\hline
\end{tabular}

Table 2 Superoxide radical scavenging activity of chloroform, ethanol and aqueous extracts of Anogeissus acuminate

\begin{tabular}{llll}
\hline \multirow{2}{*}{$\begin{array}{l}\text { Concentration } \\
(\mu \mathrm{g} / \mathrm{ml})\end{array}$} & \multicolumn{3}{l}{ Percent inhibition (mean \pm SEM) } \\
\cline { 2 - 4 } & \multicolumn{2}{l}{ Anogeissus acuminata Extract type } \\
\cline { 2 - 4 } & Choloroform & Ethanol & Aqueous \\
\hline 20 & $28.66 \pm 1.72$ & $88.84 \pm 0.08$ & $61.69 \pm 0.20$ \\
40 & $46.69 \pm 0.97$ & $91.71 \pm 0.09$ & $78.82 \pm 0.13$ \\
60 & $53.25 \pm 0.75$ & $92.97 \pm 0.04$ & $85.54 \pm 0.08$ \\
80 & $57.45 \pm 0.31$ & $93.77 \pm 0.01$ & $88.95 \pm 0.06$ \\
\hline
\end{tabular}


Table Continued..

\begin{tabular}{llll}
\hline \multirow{2}{*}{$\begin{array}{l}\text { Concentration } \\
(\mu \mathrm{g} / \mathrm{ml})\end{array}$} & \multicolumn{3}{l}{ Percent inhibition (mean \pm SEM) } \\
\cline { 2 - 4 } & \multicolumn{3}{l}{ Anogeissus acuminata Extract type } \\
\cline { 2 - 4 } Choloroform & Ethanol & Aqueous \\
\hline 100 & $63.21 \pm 0.63$ & $93.91 \pm 0.01$ & $89.61 \pm 0.09$ \\
120 & $69.99 \pm 0.15$ & $94.34 \pm 0.02$ & $93.02 \pm 0.02$ \\
140 & $76.43 \pm 0.34$ & $95.05 \pm 0.03$ & $93.86 \pm 0.01$ \\
160 & $62.98 \pm 0.23$ & $95.74 \pm 0.07$ & $93.78 \pm 0.01$ \\
180 & $56.45 \pm 0.66$ & $95.82 \pm 0.01$ & $93.55 \pm 0.02$ \\
200 & $39.31 \pm 1.32$ & $96.34 \pm 0.001$ & $93.38 \pm 0.03$ \\
220 & & $93.42 \pm 0.13$ & \\
240 & & $92.34 \pm 0.18$ & \\
260 & & $90.27 \pm 0.07$ & \\
\hline
\end{tabular}

Table 3 Nitric oxide radical scavenging activity of chloroform, ethanol and aqueous extracts of Anogeissus acuminate

\begin{tabular}{llll}
\hline \multirow{2}{*}{$\begin{array}{l}\text { Concentration } \\
(\mu \mathrm{g} / \mathrm{ml})\end{array}$} & \multicolumn{3}{l}{ Percent inhibition (mean \pm SEM) } \\
\cline { 2 - 4 } & \multicolumn{3}{l}{ Anogeissus acuminata Extract type } \\
\cline { 2 - 4 } 20 & $\begin{array}{l}\text { Choloroform } \\
\text { Ethanol }\end{array}$ & Aqueous \\
40 & $22.37 \pm 0.24$ & $23.76 \pm 0.33$ & $19.89 \pm 0.69$ \\
60 & $27.62 \pm 0.09$ & $36.74 \pm 1.37$ & $24.03 \pm 0.44$ \\
80 & $33.23 \pm 0.12$ & $45.65 \pm 1.04$ & $25.32 \pm 0.25$ \\
100 & $41.29 \pm 1.28$ & $48.41 \pm 0.47$ & $27.64 \pm 0.51$ \\
120 & $46.25 \pm 0.18$ & $55.55 \pm 0.11$ & $28.68 \pm 0.44$ \\
140 & $47.84 \pm 0.33$ & $63.14 \pm 0.44$ & $32.04 \pm 0.32$ \\
160 & $49.25 \pm 0.35$ & $67.54 \pm 0.22$ & $33.59 \pm 0.33$ \\
180 & $54.49 \pm 0.16$ & $67.76 \pm 0.29$ & $36.69 \pm 1.12$ \\
200 & $62.54 \pm 0.18$ & $71.51 \pm 0.11$ & $37.72 \pm 0.68$ \\
\hline
\end{tabular}

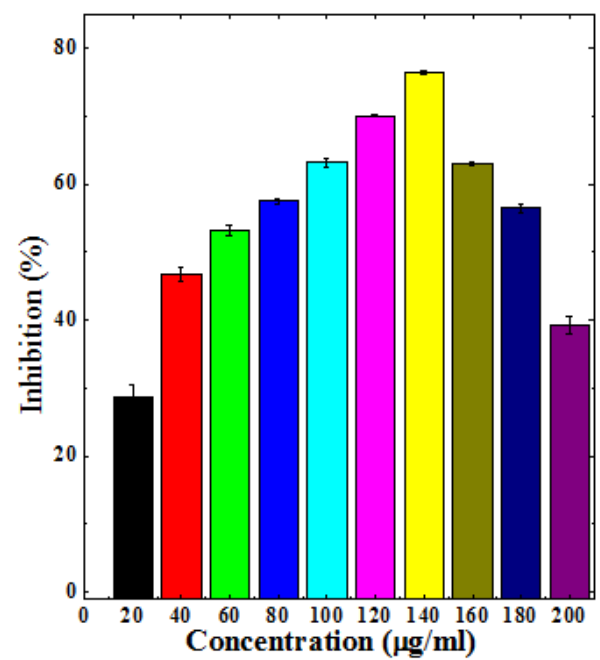

Figure I DPPH radical scavenging activity of chloroform stembark extracts of Anogeissus acuminaa.

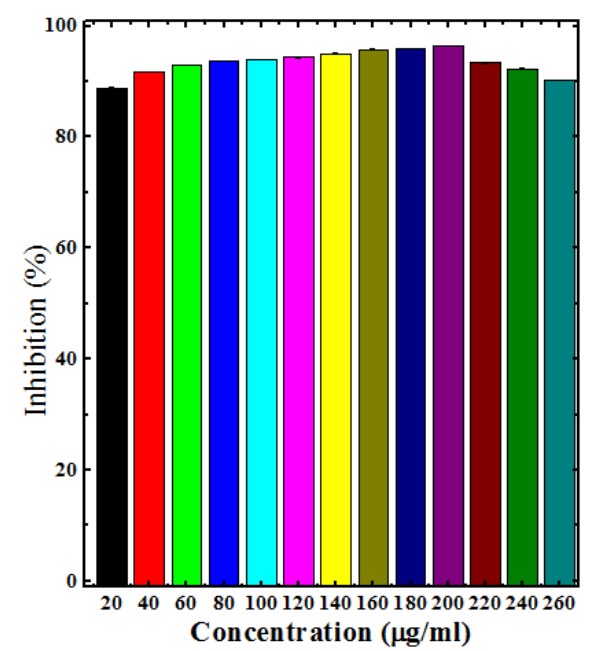

Figure 2 DPPH radical scavenging activity of ethanol stembark extracts of Anogeissus acuminata. 


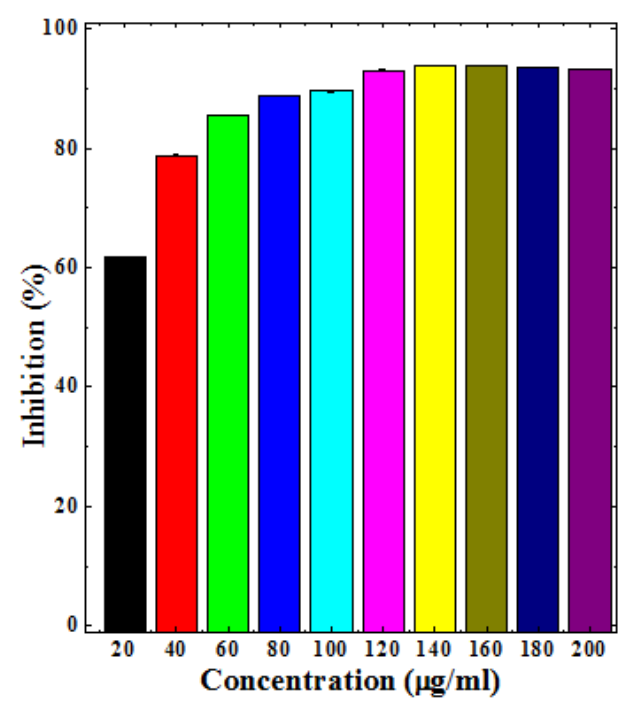

Figure 3 DPPH radical scavenging activity of aqueous stembark extracts of Anogeissus acuminata.

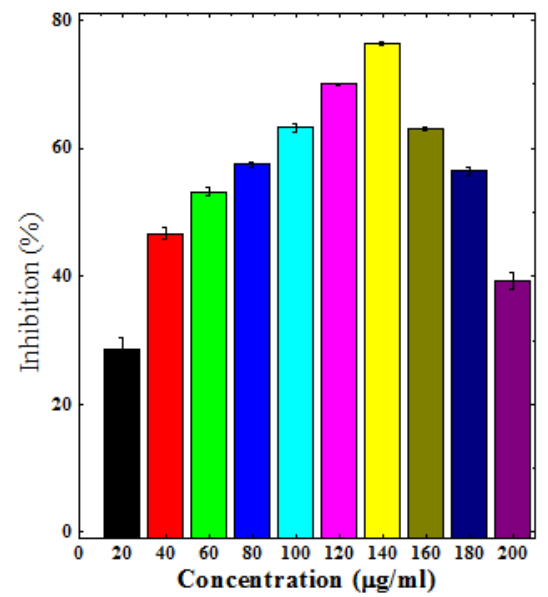

Figure 4 Superoxide radical scavenging activity of chloroform stembark extracts of Anogeissus acuminata.

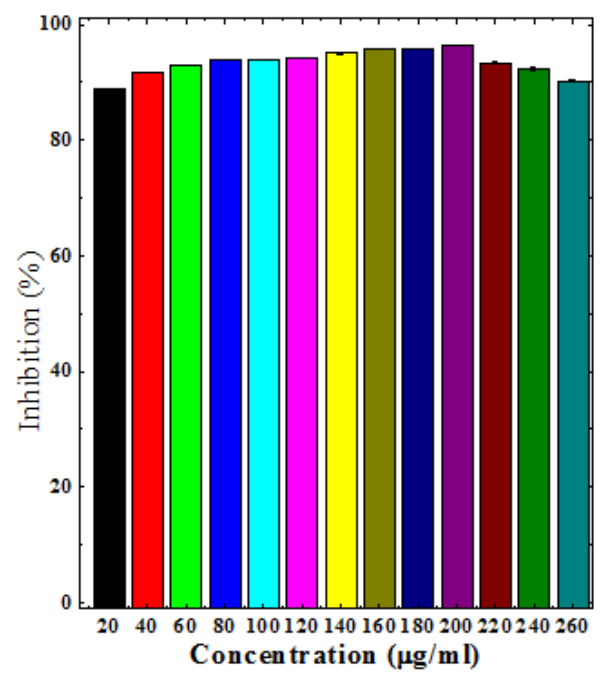

Figure $\mathbf{5}$ Superoxide radical scavenging activity of ethanol stembark extracts of Anogeissus acuminata.

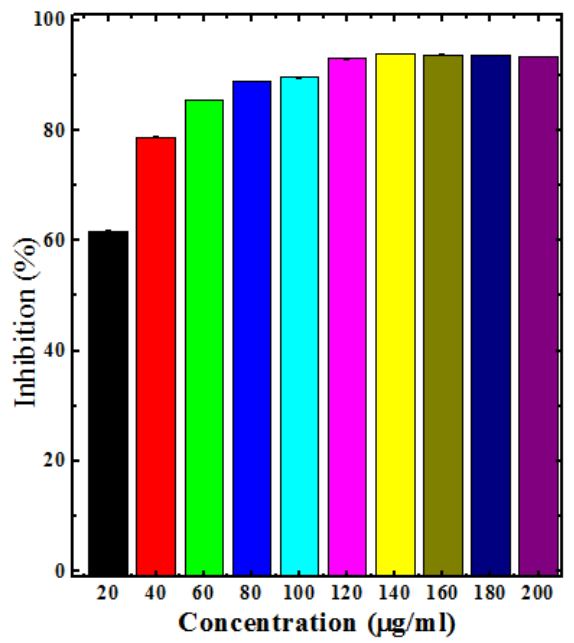

Figure 6 Superoxide radical scavenging activity of aqueous stembark extracts of Anogeissus acuminata.

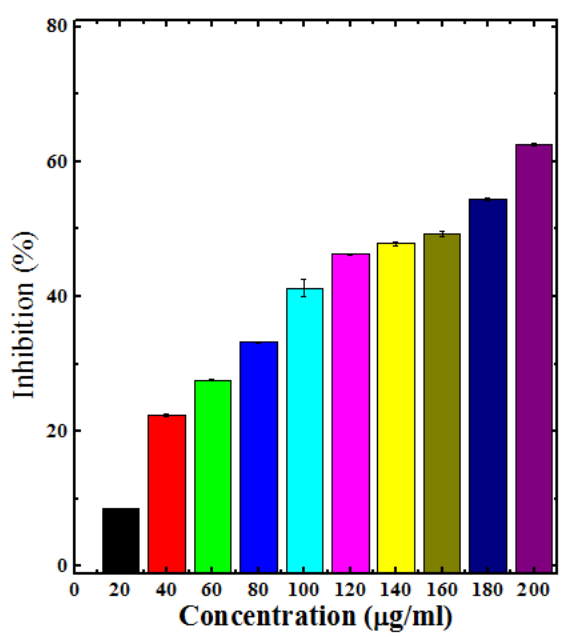

Figure 7 Nitric oxide radical scavenging activity of chloroform stembark extracts of Anogeissus acuminata.

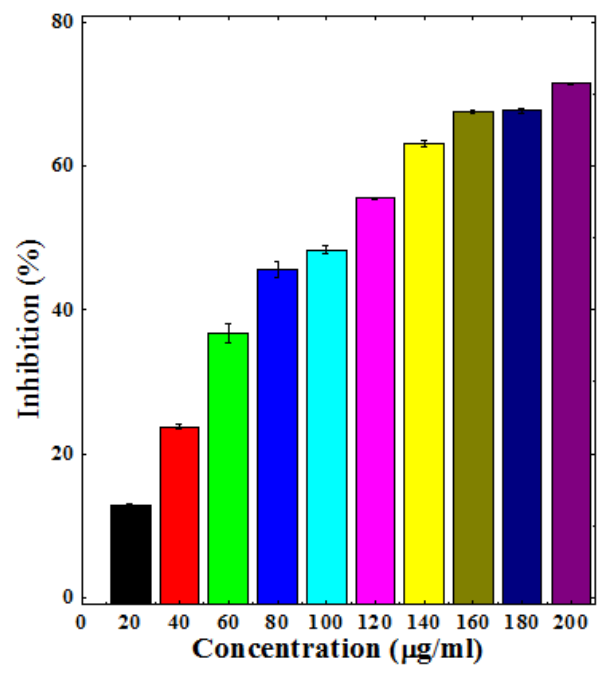

Figure 8 Nitric oxide radical scavenging activity of ethanol stembark extracts of Anogeissus acuminata. 


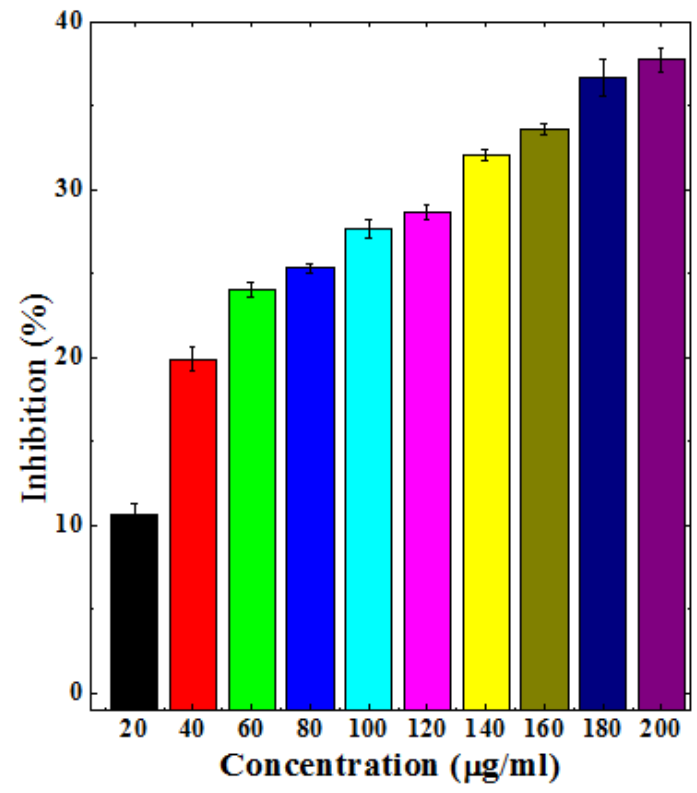

Figure 9 Nitric oxide radical scavenging activity of aqueous stembark extracts of Anogeissus acuminata.

\section{DPPH radical scavenging activity}

Stem bark extracts of Dhaura using different solvent systems inhibited the generation of DPPH free radicals with increasing concentration up to $120 \mu \mathrm{g} / \mathrm{ml}$ for chloroform $(77.24 \%)$ and aqueous $(88.85 \%)$ extracts (Table 1) (Figures 1\&3). A further increase in the chloroform and aqueous extracts led to a decline in the DPPH scavenging activity (Figures $1 \& 3$ ). The highest scavenging activity of $92.71 \%$ was detected for ethanol stem extract of Dhaura at a concentration of $80 \mu \mathrm{g} / \mathrm{ml}$ (Table 1) (Figure 2). This concentration was $40 \mu \mathrm{g} / \mathrm{ml}$ lower than chloroform and aqueous extracts, respectively (Table 1). The ethanol extract was superior in scavenging the DPPH free radical when compared to chloroform and aqueous extracts (Table 1).

\section{Superoxide scavenging activity}

Various extracts of Dhaura inhibited the production of superoxide anion radical in a concentration dependent manner (Table 2). The maximum scavenging of superoxide radical was recorded for chloroform $(76.43 \%)$ and aqueous $(93.86 \%)$ extract at a concentration of $140 \mu \mathrm{g} / \mathrm{ml}$, respectively (Table 2) (Figure $4 \& 6$ ). The ethanol extract $(96.34 \%)$ also inhibited the generation of superoxide anion radical and a maximum neutralization of superoxide anion radical was observed at $200 \mu \mathrm{g} / \mathrm{ml}$ (Table 2) (Figure 5). The chloroform extract was least effective when compared to ethanol and aqueous extracts (Table 2).

\section{Nitric oxide radical scavenging activity}

The different extracts of Dhaura led to dose dependent rise in the inhibition of nitric oxide formation (Table 3) (Figures 6-9). The maximum scavenging of nitric oxide radical was observed for chloroform, ethanol and aqueous extracts at a concentration of $200 \mu \mathrm{g} /$ $\mathrm{ml}$ (Table 3) (Figures 7-9). The aqueous extract was least effective when compared to ethanol and chloroform extracts (Table 3).

\section{Discussion}

The aerobic organisms utilize oxygen for production of chemical energy for their daily requirements. The utilization of oxygen during oxidative phosphorylation in mitochondria produce superoxide free radical, which is converted into hydrogen peroxide. Hydrogen is less toxic but is long lived and produces long term toxic effect in the tissues if not removed. ${ }^{22-24}$ However, free radicals are essential for cell signaling and to fight against the invading bacteria. ${ }^{24,25}$ Despite the fact that free radicals play an important beneficial role in cellular physiology if these free radicals are not neutralized by the endogenous system, they cause oxidative stress. The oxidative stress is indicated in inflammation and several diseases including autoimmune, cardiovascular and neurodegenerative disorders, aging, cancer rheumatoid arthritis, cataract, and diabetes. ${ }^{26,27}$ This indicates the requirement of countermeasures, which can reduce the excess production of free radicals by using pharmacological agents that are able to restrain or neutralize the formation of free radicals thereby reducing the frequency of oxidative stress induced diseases. Therefore, the present study was performed to investigate the free radical scavenging activity of stem bark extract of Dhaura, Anogeissus acuminata.

Estimation of DPPH scavenging is a convenient method to study the antioxidant activity of any pharmacological agent. 1,1diphenyl-2-picrylhydrazyl (DPPH) possesses a free electron and is violet coloured, which changes its colour to yellow when it accepts electron from any antioxidants and is converted into DPPH-H. Stem bark extract of Dhaura using different solvent systems inhibited the generation of DPPH free radicals in a concentration dependent manner. Various extracts of Dhaura showed a concentration dependent elevation in the scavenging of DPPH radical up to $120 \mu \mathrm{g} / \mathrm{ml}$ for chloroform and aqueous extracts and $80 \mu \mathrm{g} / \mathrm{ml}$ for ethanol extract. Similarly, the chloroform, ethanol and water extracts of Croton caudatus, Colocasia gigantea, Oroxylum indicum, Schima wallichii and Mimosa pudica have been reported to scavenge DPPH radical in a dose dependent fashion. ${ }^{28-31}$. The other plant extracts Including Aegel marmelos, Syzygium cumini, Milletia pachycarpa, Eleagnus caudata, Dysoxylum gobara, Castanopsis indica and Mimosa pudica have been found to inhibit the generation of DPPH radicals earlier. ${ }^{32-38}$ This DPPH scavenging activity may be due to the presence of flavonoids and other polyphenols in the Dhaura. ${ }^{15}$

The superoxide anion free radical is generated as an intermediate during cellular respiration, which is produced as a result of incomplete metabolism of oxygen. ${ }^{39,40}$ The superoxide anion produces $\mathrm{H}_{2} \mathrm{O}_{2}$, which in turn generates hydroxyl free radicals in the presence of metal ions, which are highly reactive and damage important cellular macromolecules like lipids, DNA and proteins. ${ }^{41-43}$ Thus, neutralization of superoxide radical will inhibit the chain of ROS generation and protect cells from oxidative stress. The chloroform, ethanol and water extracts of Dhaura have been found to inhibit the production of superoxide radical in a concentration dependent manner. The chloroform, ethanol and water extracts of Croton caudatus, Colocasia gigantea, Oroxylum indicum, Schima wallichii and Mimosa pudica have been reported to scavenge superoxide radical in a dose dependent fashion. ${ }^{28-31}$ The superoxide radical scavenging activity of Dhaura may be due to the presence of several phytochemicals including flavonoid and polyphenols which have been detected earlier. ${ }^{15}$

The nitric oxide radical is a labile molecule, which is generated in mammalian cells for nerve transmission and to fight infection by neutrophils..$^{22,24,44}$ However excess production of nitric oxide is toxic, especially after reaction with oxygen or superoxide anion radicals. The reaction products of nitric oxide including NOx and ONOO-(peroxynitrite) are able to inflict severe cellular damage and pathogenesis. ${ }^{45,46}$ The chloroform, ethanol and aqueous extracts of Dhaura reduced the generation of nitric oxide in a concentration dependent manner. Several plant extracts including Foeniculum vulgare, Citrus limettiodes, Murraya koenigii, Curcuma aromatica 
Mentha arvensis, Curcuma longa, Gingko biloba, and Zingiber officinale have been reported to scavenge NO radical earlier. ${ }^{34}$ Certain plant formulations have been also reported to scavenge nitric oxide in a concentration dependent manner ${ }^{47}$ Similarly, Alstonia scholaris, Cynodon dactylon, Morinda citrifolia, Tylophora indica, Tectona grandis, Aegle marmelos, Momordica charantia, Phyllanthus niruri, Ocimum sanctum, Tinospora cordifolia, Coleus ambonicus, Vitex negundo, Ipomoea digitate, Boerhaavia diffusa, Picrorrhiza kurroa Santalum album and Eugenia jambolana have been reported to passivate NO radicals earlier. ${ }^{48}$ The NO inhibitory action of Dhaura may be due to the presence different phytochemicals including flavonoids and other polyphenols. ${ }^{15}$

\section{Conclusions}

The chloroform, ethanol and aqueous extracts of Dhaura, Anogeissus acuminata inhibited the generation of DPPH, superoxide and nitric oxide depending on their concentration. This free radical scavenging ability of Dhaura may be due to the presence of flavonoids and other polyphenols. The medicinal use of Dhaura may be linked to its ability to scavenge various free radicals.

\section{Acknowledgements}

A grant from University Grants Commission, Government of India, and New Delhi to GCJ supported the work carried out in this study.

\section{Conflicts of interest statement}

The authors have no conflicts of interest statement to declare.

\section{References}

1. Fransen M, Nordgren M, Wang B, et al. Aging, age-related diseases and peroxisomes. Subcell Biochem. 2013;69:45-65.

2. Lismont C, Nordgren M, Van Veldhoven PP, et al. Redox interplay between mitochondria and peroxisomes. Fron Cell Develop Biol. 2015;3:35.

3. Pascual-Ahuir A, Manzanares-Estreder S, Proft M. Pro-and antioxidant functions of the peroxisome-mitochondria connection and its impact on aging and disease. Oxid Med Cell Long. 2017;2017.

4. Spitz DR, Hauer-Jensen M. Ionizing radiation-induced responses: where free radical chemistry meets redox biology and medicine. Antioxid Redox Signal. 2014;20(9):1407-1409.

5. Zhou Z, Song J, Nie L, et al. Reactive oxygen species generating systems meeting challenges of photodynamic cancer therapy. Chem Soc Rev. 2016;45(23):6597-6626.

6. Banerjee S, Ghosh J, Sil PC. Drug metabolism and oxidative stress: cellular mechanism and new therapeutic insights. Biochemistry \& Analytical Biochemistry. 2016;5(225):2161-1009.

7. Kıvrak EG, Yurt KK, Kaplan AA, et al. Effects of electromagnetic fields exposure on the antioxidant defense system. J Microsc Ultrastruct. 2017;5(4):167-176.

8. Lohan SB, Müller R, Albrecht S, et al. Free radicals induced by sunlight in different spectral regions-in vivo versus ex vivo study. Exp Dermatol. 2016;25(5):380-385.

9. Kehrer JP, Klotz LO. Free radicals and related reactive species as mediators of tissue injury and disease: implications for health. Crit Rev Toxicol. 2015;45(9):765-798.

10. Ghezzi P, Jaquet V, Marcucci F, et al. The oxidative stress theory of disease: levels of evidence and epistemological aspects. Br J Pharmacol. 2017;174(12):1784-1796.
11. Liguori I, Russo G, Curcio F, et al. Oxidative stress, aging, and diseases. Clin Intervent Aging. 2018;13:757-772.

12. Silva MM, Lidon FC. An overview on applications and side effects of antioxidant food additives. Emirates Journal of Food and Agriculture. 2016;28(2):823-832.

13. Sarangarajan R, Meera S, Rukkumani R, et al. Antioxidants: Friend or foe? Asian Pac J Trop Med. 2017;10(12):1111-1116.

14. Zaruwa MZ, Manosroi J, Akihisa T, et al. Castalagin from Anogeissus acuminata (Roxb. ex. DC) Guill. Ex. Perr, a potent hypoglycaemic agent. Int J Curr Res Aca Rev. 2015;3(7):147-152.

15. Jagetia G C, Laltanpuia. Detection of Phytochemicals in the Different Extracts of Dhaura, Anogeissus Acuminata (Roxb.) Wall. Ex Bedd. Pharma Sci Analytical Res J. 2018;1(2):180008.

16. Singh D, Baghel US, Gautam A, et al. The genus Anogeissus: A review on ethnopharmacology, phytochemistry and pharmacology. J Ethnopharmacol. 2016;194:30-56.

17. Hemamalini K, Vijusha M. Antidiabetic activity of methanolic extracts of leaves of Anogeissus acuminata Roxburgh ex candolle and Solanum pubescens Willd by alloxan induced model in rats. Der Pharm Lett. 2012;4(5):1445-1460.

18. Singh D, Baghel US, Pannu MS, et al. Ethnopharmacological based evaluation of Anogeissus pendula Edgew extracts for antioxidant and hepatoprotective potential. Anc Sci Life. 2017;36(3):136-140.

19. Leong LP, Shui G. An investigation of antioxidant capacity of fruits in Singapore markets. Food Chem. 2000;76(1):69-75.

20. Hyland K, Voisin E, Banoun H, et al. Superoxide dismutase assay using alkaline dimethylsulfoxide as superoxide anion-generating system. Anal Biochem. 1983;135(2):280-287.

21. Marcocci L, Packer L, Droy-Lefaix MT. Antioxidant action of Ginkgo biloba extract EGb 761. Methods Enzymol. 1994;234:462-475.

22. Droge W. Free radicals in the physiological control of cell function. Physiol Rev. 2002;82(1):47-95.

23. Weidinger A, Kozlov A. Biological activities of reactive oxygen and nitrogen species: oxidative stress versus signal transduction. Biomolecules. 2015;5(2):472-484.

24. Radi R. Oxygen radicals, nitric oxide, and peroxynitrite: Redox pathways in molecular medicine. Proc Natl Acad Sci. 2018;115(23):5839-5848.

25. Posen Y, Kalchenko V, Seger R, et al. Manipulation of redox signaling in mammalian cells enabled by controlled photogeneration of reactive oxygen species. J Cell Sci. 2005;118(9):1957-1969.

26. Valko M, Leibfritz D, Moncol J. Free radicals and antioxidants in normal physiological functions and human disease. Int J Biochem Cell Biol. 2007;39(1):44-84.

27. Kehrer JP, Klotz LO. Free radicals and related reactive species as mediators of tissue injury and disease: implications for health. Crit Rev Toxicol. 2015;45(9):765-98.

28. Shantabi L, Jagetia GC, Ali MA, Singh TT, Devi SV. Antioxidant potential of Croton caudatus leaf extract in vitro. Transl Med Biotech. 2014;2(6):1-15.

29. Lalrinzuali K, Vabeiryureilai M, Jagetia GC, et al. Free radical scavenging and antioxidant potential of different extracts of Oroxylum indicum in vitro. Adv Biomed Pharm. 2015;2(3):120-130.

30. Devi NB, Jagetia GC. Free radical scavenging and antioxidant potential of different extracts of Colocasia gigantea (Blume) Hook. F. In vitro. Int Res J Pharm. 2017;8(10):72-81. 
31. Lalhminghlui K, Jagetia GC. Evaluation of the Free radical scavenging and antioxidant activities of Chilauni, Schima wallichii Korth in vitro. Future Sci OA. 2018;4(2):FSO272.

32. Jagetia GC, Venkatesh P, Baliga MS. Evaluation of the radioprotective effect of Aegle marmelos (L.) Correa in cultured human peripheral blood lymphocytes exposed to different doses of $\gamma$-radiation: a micronucleus study. Mutagenesis. 2003;18(4):387-393.

33. Jagetia GC, Shetty PC, Vidyasagar MS. Inhibition of radiation-induced DNA damage by jamun, Syzygium cumini in the cultured splenocytes of mice exposed to different doses of $\gamma$-radiation. Integr Cancer Ther. 2012;11(20:141-153.

34. Baliga MS, Jagetia GC, Rao SK, et al. Evaluation of nitric oxide scavenging activity of certain spices in vitro: A preliminary study. Nahrung. 2003;47(4):261-264

35. Wong SP, Lai PL, Jen HWK. Antioxidant activities of aqueous extracts of selected plants. Food Chem. 2006;99:775-783.

36. Aparadh VT, Naik VV, Karadge BA. Antioxidative properties (TPC DPPH, FRAP, metal chelating ability, reducing power and TAC) within some cleome species. Ann Bot (Roma). 2012;2:49-56.

37. Lalrinzuali K, Vabeiryureilai M, Jagetia GC. The analysis of antioxidant activity and phenolic contents of selected medicinal plants of Mizoram. Genomics and Applied Biology. 2016;6(11):1-12.

38. Jagetia GC, Lalhmangaihi C. Phytochemical profiling and antioxidan activity of Lajwanti Mimosa pudica Linn. in vitro. Int J Plant Stud. 2018;1(1):1-13.

39. Kirkinezos IG, Moraes CT. Reactive oxygen species and mitochondrial diseases. Seminn Cell Develop Biol. 2001;12(6):449-457.
40. Brand MD. Mitochondrial generation of superoxide and hydrogen peroxide as the source of mitochondrial redox signaling. Free Radic Biol Med. 2016;100:14-31.

41. Kohen R, Nyska A. Oxidation of biological systems: oxidative stress phenomena, antioxidants, redox reactions, and methods for their quantification. Toxicol Pathol. 2002;30(6):620-650.

42. Nikitaki Z, Hellweg CE, Georgakilas AG, et al. Stress-induced DNA damage biomarkers: applications and limitations. Front Chem. 2015;3:35.

43. Barrera G. Oxidative stress and lipid peroxidation products in cancer progression and therapy. ISRN Ooncol. 2012;2012.

44. Garthwaite J. From synaptically localized to volume transmission by nitric oxide. J Physiol. 2016;594(1):9-18.

45. Tejero J, Shiva S, Gladwin MT. Sources of vascular nitric oxide and reactive oxygen species and their regulation. Physiol Rev. 2018;99(1):311379.

46. Lundberg JO, Weitzberg E, Gladwin MT. The nitrate-nitrite-nitric oxide pathway in physiology and therapeutics. Nat Rev Drug Discov. 2008;7(2):156.

47. Jagetia GC, Rao SK, Baliga MS, et al. The evaluation of nitric oxide scavenging activity of certain herbal formulations in vitro: a preliminary study. Phytother Res. 2004;18(7):561-565.

48. Jagetia GC, Baliga MS. The evaluation of nitric oxide scavenging activity of certain Indian medicinal plants in vitro: a preliminary study. $J \mathrm{Med}$ Food. 2004;7(3):343-348. 